\title{
WHY SO SERIOUS?: EARLY ANALYSIS OF THE DEFINITION OF "SERIOUS IMPAIRMENT" UNDER ALBERTA's MINOR INJURY REGULATION
}

\author{
Christine J. PRATT, BRIAN D. FILIPS, ${ }^{* *}$ \\ DANIELLE BOURGEOIS, ${ }^{* * *}$ AND ARTEM BARSUKOV ${ }^{* * * *}$
}

This article examines the interpretation of "serious impairment" as defined in Alberta's Minor Injury Regulation (MIR). It first assesses the similarities and differences between the definitions of serious impairment found in the MIR and similar legislation from several provinces. It then discusses the five factors required to find a serious impairment proposed by Justice Shelly in Sparrowhawk v. Zapoltinsky, and interprets the factors using case law from other provincial jurisdictions. The article concludes that the Alberta MIR is distinct in three major aspects. Therefore, non-Alberta jurisprudence must be approached with caution, but may nevertheless be of some value in interpreting the Alberta regulation.

\begin{abstract}
Cet article examine l'interprétation de « invalidité grave » (serious impairment) telle qu'elle se définit dans le Règlement sur les blessures mineures (Minor Injury Regulation (MIR)) de l'Alberta. L'auteur commence par considérer les similitudes et les différences entre les définitions d'invalidité grave du Règlement et les lois semblables de plusieurs provinces. Il traite ensuite des cinq facteurs nécessaires pour déterminer une invalidité grave proposés par la juge Shelly dans Sparrowhawk c. Zapoltinsky, et interprète les facteurs en utilisant la jurisprudence des autres provinces. L'auteur conclut que le Règlement de l'Alberta se distingue sur trois aspects. Par conséquent il faut aborder la jurisprudence non albertaine avec prudence, bien qu'elle puisse être utile pour interpréter la réglementation de l'Alberta.
\end{abstract}

\section{TABLE OF CONTENTS}

I. INTRODUCTION . . . . . . . . . . . . . . . . . . . . . . . . . 660

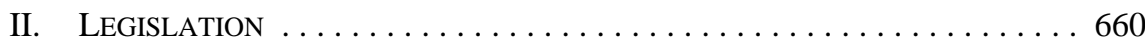

A. Alberta . . . . . . . . . . . . . . . . . . . . . . 660

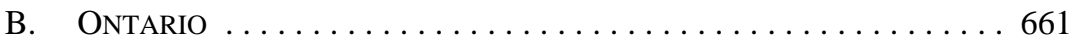

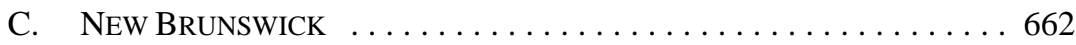

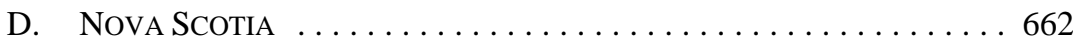

E. Similarities ACROSS JURISDICTIONS $\ldots \ldots \ldots \ldots \ldots \ldots \ldots \ldots 62$

F. DIFFERENCES BETWEEN JURISDICTIONS $\ldots \ldots \ldots \ldots \ldots \ldots 66$

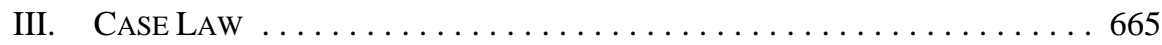

A. "Serious ImPairment”" in CANADA GENERALly . . . . . . . . 665

B. The Alberta Court of QueEn's Bench Decision in SPARROWHAWK V. ZAPOLTINSKY ................. 667

C. CANADIAN CASE LAW ON THE "SERIOUS IMPAIRMENT" FACTORS IDENTIFIED IN SPARROWHAWK . . . . . . . . . . . 668

Partner and civil litigator with Field LLP, Edmonton, Alberta. She graduated from the University of

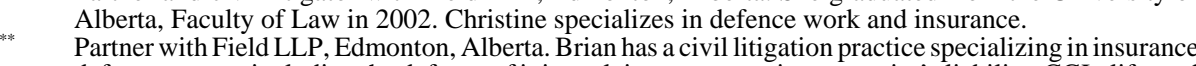
defence matters including the defence of injury claims, construction, occupier's liability, CGL, life, and disability.

*** Associate with Field LLP, Edmonton, Alberta. Danielle graduated from the University of Alberta, Faculty of Law in 2009. Danielle was admitted to the Alberta bar in 2010.

**** Associate with Bennett Jones LLP, Edmonton, Alberta, where he maintains a general corporate/ commericial practice. Prior to his admission to the Alberta bar, Artem clerked with the Honourable Madam Justice JM Ross of the Alberta Court of Queen's Bench. 


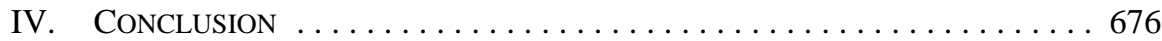

APPENDIX: SERIOUS IMPAIRMENT ACROSS JURISDICTIONS . . . . . . . 677

\section{INTRODUCTION}

In 2004, Alberta passed the Minor Injury Regulation, ${ }^{1}$ which imposed a cap of $\$ 4,000$ on non-pecuniary general damages for injuries defined as "minor" under the MIR. The regulation was thereafter upheld by the Alberta Court of Appeal in Morrow v. Zhang, ${ }^{2}$ with leave to appeal to the Supreme Court of Canada dismissed.

Section 1 of the MIR defines a "minor injury" as a sprain, strain, or whiplash-associated disorder (WAD) caused by an accident that does not result in a "serious impairment."3 The term "serious impairment" is central to the definition of a minor injury and is widely used within the context of minor injury caps in other jurisdictions, such as Ontario, New Brunswick, and Nova Scotia. In Alberta, the definition of a serious impairment has been commented on most notably in Sparrowhawk v. Zapoltinsky. ${ }^{4}$ In this article, we touch on the analysis in Sparrowhawk and further explore the benefits and limitations of relying upon case law from New Brunswick, Nova Scotia, and, especially, Ontario, in respect of future litigation concerning the definition of a serious impairment in Alberta.

\section{LEGISLATION}

\section{A. Alberta}

In Alberta, “serious impairment” is defined under section 1 of the MIR as follows:

“[S]erious impairment”, in respect of a claimant, means an impairment of a physical or cognitive function

(i) that results in a substantial inability to perform the

(A) essential tasks of the claimant's regular employment, occupation or profession, despite reasonable efforts to accommodate the claimant's impairment and the claimant's reasonable efforts to use the accommodation to allow the claimant to continue the claimant's employment, occupation or profession,

(B) essential tasks of the claimant's training or education in a program or course that the claimant was enrolled in or had been accepted for enrolment in at the time of the accident, despite reasonable efforts to accommodate the claimant's impairment and the claimant's reasonable efforts to use the accommodation to allow the claimant to continue the claimant's training or education, or

(C) normal activities of the claimant's daily living, 
(ii) that has been ongoing since the accident, and

(iii) that is expected not to improve substantially. ${ }^{5}$

\section{B. ONTARIO}

In Ontario, the Insurance Act ${ }^{6}$ has been changed several times since 1990 to create slightly different minor injury definitions for different time periods, and there is a different applicable regulation that further refines the definitions for most of these time periods. For the sake of brevity, we cite only the most recent definition, applicable to accidents arising after 1 November 1996.

The Ontario legislation will permit recovery of non-pecuniary damages where there is a "permanent serious impairment of an important physical, mental or psychological function.", This phrase is further defined in the Court Proceedings for Automobile Accidents that Occur On or After November 1, 1996 Regulation, ${ }^{8}$ which states as follows:

A person suffers from permanent serious impairment of an important physical, mental or psychological function if all of the following criteria are met:

1. The impairment must,

i. substantially interfere with the person's ability to continue his or her regular or usual employment, despite reasonable efforts to accommodate the person's impairment and the person's reasonable efforts to use the accommodation to allow the person to continue employment,

ii. substantially interfere with the person's ability to continue training for a career in a field in which the person was being trained before the incident, despite reasonable efforts to accommodate the person's impairment and the person's reasonable efforts to use the accommodation to allow the person to continue his or her career training, or

iii. substantially interfere with most of the usual activities of daily living, considering the person's age.

2. For the function that is impaired to be an important function of the impaired person, the function must,

i. be necessary to perform the activities that are essential tasks of the person's regular or usual employment, taking into account reasonable efforts to accommodate the person's impairment and the person's reasonable efforts to use the accommodation to allow the person to continue employment,

ii. be necessary to perform the activities that are essential tasks of the person's training for a career in a field in which the person was being trained before the incident, taking into account reasonable 
efforts to accommodate the person's impairment and the person's reasonable efforts to use the accommodation to allow the person to continue his or her career training,

iii. be necessary for the person to provide for his or her own care or well-being, or

iv. be important to the usual activities of daily living, considering the person's age.

3. For the impairment to be permanent, the impairment must,

i. have been continuous since the incident and must, based on medical evidence and subject to the person reasonably participating in the recommended treatment of the impairment, be expected not to substantially improve,

ii. continue to meet the criteria in paragraph 1 , and

iii. be of a nature that is expected to continue without substantial improvement when sustained by persons in similar circumstances. ${ }^{9}$

\section{NEW BRUNSWICK}

In a manner similar to Alberta and Ontario, New Brunswick defines its "minor personal injury" as one that did not result in, inter alia, "permanent serious impairment of an important bodily function caused by continuing injury which is physical in nature." 10 A permanent "serious impairment" is further defined in the Injury Regulation as "an impairment that causes substantial interference with a person's ability to perform their usual daily activities or their regular employment."11

\section{Nova Scotia}

Finally, in Nova Scotia, section $113 \mathrm{~B}(4)$ of the Insurance Act, ${ }^{12}$ similarly limits liability for minor injuries to the cap set in the regulations. A "minor injury" is a "personal injury" that does not "result in a permanent serious disfigurement," does not "result in a permanent serious impairment of an important bodily function caused by a continuing injury which is physical in nature," and is resolved within 12 months of the accident. ${ }^{13}$ "Serious impairment" is defined as "an impairment that causes substantial interference with a person's ability to perform their usual daily activities or their regular employment." ${ }^{\text {,4 }}$

\section{E. Similarities ACROSS JURISDiCTIONS}

In all of the four jurisdictions the impairment must be permanent in order to fully satisfy the definition. Alberta is the only jurisdiction that does not use the expression "permanent

Ibid, s. 4.2(1).

Injury Regulation - Insurance Act, NB Reg 2003-20, s 2(2)(b) [Injury Regulation].

Ibid.

RSNS 1989, с 231.

Ibid, s 113B(1)(a).

Ibid, s 113B(1)(b). 
serious impairment"; instead, it simply requires that a serious impairment be "ongoing since the accident" and "expected not to improve substantially." The other jurisdictions use the word "permanent" and define it largely in the same way, subject to a few differences that will be discussed below.

Furthermore, all four jurisdictions cite regular employment and usual (or normal) activities of daily living as activities with which the impairment must interfere in order to satisfy the definition. Ontario and Alberta both go a step further and allow claimants to escape a minor injury cap where the impairment substantially interferes with their training. Finally, all jurisdictions except New Brunswick state that the impairment must interfere with the essential tasks (or elements) of employment and training in order to interfere with the said employment and training.

All jurisdictions except New Brunswick also require that the impairment interfere with the said activities despite reasonable efforts to accommodate and the claimant's reasonable efforts to use the accommodation. That this requirement is so seemingly uniform is not an accident; it is a mere codification of the common law duty to mitigate one's loss and has been recognized as such in Ontario. ${ }^{15}$ In light of this, it is likely that accommodation will be considered as a factor in New Brunswick despite its absence from the Injury Regulation.

\section{F. DIFFERENCES BETWEEN JURISDICTIONS}

Although all jurisdictions require that the impairment be permanent, they define "permanent" in slightly different ways. In Alberta, the impairment must simply be (1) ongoing since the accident and (2) expected not to improve substantially. Ontario raises this threshold by requiring that, in addition to the above two requirements, the impairment be continuous, subject to the claimant reasonably participating in the recommended treatment. Ontario also requires that the impairment be continuous and based on medical evidence, although it is possible to argue that this requirement is implied in the Alberta legislation. Finally, in New Brunswick the injury must simply be "continuing," and in Nova Scotia it cannot resolve within 12 months following the accident.

The four jurisdictions also differ in the kind of functions they allow to be affected by a serious impairment. Alberta follows a moderate approach requiring that the impairment relate to a physical or cognitive function. According to the Oxford English Dictionary, the term "cognitive" is quite narrow, denoting items pertaining specifically to the process of knowing. ${ }^{16}$ Ontario follows the broadest approach, allowing the impairment to affect any important physical, mental, or psychological function. The term "mental" is much broader than the term "cognitive" used in Alberta and refers to "senses relating to the human mind in the most general sense." ${ }^{17}$ Both New Brunswick and Nova Scotia follow the narrowest approach and limit serious impairment to that affecting an important bodily function that is physical in nature. 
By far the most important difference between Alberta and the other jurisdictions is Alberta's use of the words "substantial inability to perform" instead of "substantial interference with a person's ability to perform." While interference may simply have an effect of hampering or hindering a process ${ }^{18}$ the term "inability" connotes complete "lack of power, capacity, or means." ${ }^{19}$ Combined with the word "substantial," the complete phrase "substantial inability" suggests a significantly higher threshold than the phrase "substantial interference" used in other jurisdictions.

Another significant difference between Alberta and the other jurisdictions is the reference to impairment of an important bodily function, which is completely missing from the Alberta MIR. This removes an important qualifier present in the Ontario, New Brunswick, and Nova Scotia legislation and renders some non-Alberta case law on the definition of an important bodily function largely irrelevant to MIR litigation in Alberta. Ontario case law may still provide some value in deciding what constitutes essential tasks of the claimant's regular employment, as the Ontario definition of an important bodily function states that such function must be necessary to perform these essential tasks. ${ }^{20}$

While both Alberta and Ontario treat training the same way as regular employment, they define training in slightly different ways. In Ontario, a serious impairment may extend only to training for a career "in a field in which the person was being trained before the incident." ${ }^{21}$ Alberta follows a much more generous approach, allowing a serious impairment to extend to any training that the claimant "was enrolled in or had been accepted for enrolment in at the time of the accident." 22

Compared to the other jurisdictions, Ontario also imposes a somewhat higher threshold with regard to interference with activities of daily living. The Ontario Court Proceedings Regulation requires that the impairment interfere with most activities of a claimant's daily living; ${ }^{23}$ such a requirement is absent in other jurisdictions. This was recognized as a significant difference by the Ontario Superior Court of Justice in Nissan, which viewed the addition of "most" as implying that "it is not enough that an impairment substantially interfere with 'some' activities of daily living, but that there must be a full consideration of the import of the activities that have been interfered with." ${ }^{24}$

The Ontario legislation also incorporates an objective element, missing in Alberta's legislation, in its definition of both "important bodily function" and "permanent." The Ontario legislation provides that the assessment of whether the impairment substantially interferes with most of the usual activities of daily living (to determine if it is "important") must be done "considering the person's age."25 The Ontario Court in Nissan suggested that such a requirement required the "continuation of a mixture of subjective and objective

Ibid, sub verbo "interfere."

Ibid, sub verbo "inability."

Court Proceedings Regulation, supra note 8, s 4.2(1)(2)(ii).

Ibid.

MIR, supra note 1 , s $1(\mathrm{j})(\mathrm{i})(\mathrm{B})$.

Supra note 8, s 4.2(1)(1)(iii).

Supra note 15 at para 26.

Court Proceedings Regulation, supra note 8, s 4.2(1)(1)(iii). 
considerations" ${ }^{26}$ in assessing the importance of the impairment. The Alberta legislation focuses on the "normal activities of the claimant's daily living," 27 impliedly suggesting a more subjective test that will take into account the claimant's age, physical condition, and other relevant personal factors, without reference to the usual activities common among the claimant's age cohorts.

Finally, Ontario defines permanent impairment as requiring the impairment "be of a nature that is expected to continue without substantial improvement when sustained by persons in similar circumstances." 28 The Ontario Superior Court in Nissan interpreted the words "similar circumstances" as requiring a comparison with a group suffering from the same condition. ${ }^{29}$ The Alberta MIR lacks a reference to "persons in similar circumstances," simply requiring that the impairment be "expected not to improve substantially." 30 The Ontario case suggests that an impairment that is permanent for a particular plaintiff might not be considered permanent if that state of affairs is unreasonable given the plaintiff's circumstances, while Alberta's legislation does not contain such an opening in the "permanent" definition. It does, however, require that the accident be the "primary contributing factor" to the impairment, ${ }^{31}$ thereby attempting to deal with the material contribution test found in Athey v. Leonati. ${ }^{32}$

\section{CASE LAW}

\section{A. “SERIOUS IMPAIRMENT” IN CANADA GENERALLY}

The definition of a serious impairment in Canada stemmed from the seminal 1993 decision of the Ontario Court of Appeal in Meyer v. Bright..$^{33}$ In that case, the Court dealt with the original wording of section 266 of the Ontario Insurance Act, which barred liability unless the plaintiff sustained "permanent serious impairment of an important bodily function caused by continuing injury which is physical in nature." 34 That version of the Insurance Act did not include any explanatory definitions such as those found today in Ontario's Court Proceedings Regulation.

The Court in Meyer noted that serious impairment did not mean "significant" or "approaching catastrophic." ${ }^{35}$ The Court also observed that "an impairment of an important bodily function which is serious to one person may not necessarily be a serious one for someone else,"36 and that each case must be decided upon its own facts. The Court did find, however, that generally "a serious impairment is one which causes substantial interference with the ability of the injured person to perform his or her usual daily activities or to continue his or her regular employment." ${ }^{\text {} 77}$ This comment was incorporated, nearly verbatim, in the

Supra note 15 at para 24.

MIR, supra note 1, s $1(\mathrm{j})(\mathrm{i})(\mathrm{C})$.

Court Proceedings Regulation, supra note 8, s 4.2(1)(3)(iii).

Supra note 15 at para 36.

Supra note 1, s 1(j)(iii).

Ibid, s 3.

[1996] 3 SCR 458.

(1993), 15 OR (3d) 129 (CA) [Meyer].

Supra note 6, s 266(1)(b).

Supra note 33 at 141-42.

Ibid at 142 .

Ibid. 
most recent iteration of the definition as found in section 4.2(1) of the Court Proceedings Regulation and, eventually, into the definition of a "serious impairment" within the Alberta MIR. ${ }^{38}$

The Court also emphasized the presence of the word "serious" as an important qualifier to serious impairment claims. The Court specifically stated that "[w]hen the Legislature qualified 'permanent impairment' by the word 'serious' it obviously intended that injured persons must endure some permanent impairment without being able to sue.”39

Applying this statement of law to the facts in Meyer, the Court found that Mrs. Meyer did not have a serious impairment. Meyer had sustained a fracture of her left patella, a fracture of her right wrist, and a number of soft tissue injuries. After the accident, Meyer was limited in many of her activities (walking, vacuuming, working with heavy objects, and meal preparation for large groups), and the Court concluded that there was a detrimental impact on Meyer's enjoyment of life. However, the Court found that the detrimental impact was not of such a degree as to constitute a serious impairment. ${ }^{40}$

However, in the 2008 decision in Brak v. Walsh, ${ }^{41}$ the Court of Appeal refined its approach to serious impairment, and it specifically did so vis-à-vis the analysis of the effect the impairment has on the normal activities of the claimant's daily living. The Court set out the now-accepted test for the "seriousness" of the impairment:

\footnotetext{
The requirement that the impairment be "serious" may be satisfied even although plaintiffs, through determination, resume the activities of employment and the responsibilities of household but continue to experience pain. In such cases it must also be considered whether the continuing pain seriously affects their enjoyment of life, their ability to socialize with others, have intimate relations, enjoy their children, and engage in recreational pursuits. ${ }^{42}$
}

Therefore, at least with regard to the pain experienced by a claimant, his or her impairment may be considered serious notwithstanding that he or she is able to return to work and look after his or her personal needs.

For instance, in Whilby $v$. Redhead ${ }^{43}$ the defendant brought a motion for dismissal of the plaintiff's non-pecuniary damages. The defendant based his submissions on the fact that the plaintiff had been able to preserve his employment and occasionally perform as a musician on the side. The Ontario Superior Court of Justice dismissed the motion. While the plaintiff had been able to keep his employment, he could not perform at the same level he did before the accident. Moreover, there was no indication that his impairments would go away in the future. The Court determined that the life of the plaintiff had been seriously impacted by his injuries. $^{44}$

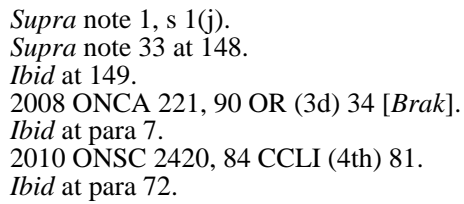


Similarly, in Nicolas v. Bowers ${ }^{45}$ the plaintiff carried on with her employment. In this case, her employer eliminated certain job functions so she could perform assigned tasks without much difficulty. Still, the Ontario Superior Court of Justice found that the plaintiff's residual symptoms caused her serious problems with ever increasing frequency. Specifically, the Court highlighted the fact that her current pain affected her ability to fully experience intimacy with her husband and her ability to entertain her extended family without help from others. $^{46}$

\section{B. The Alberta Court OF QUEEN's BENCH DECISION IN SPARROWHAWK V. ZAPOLTINSKY}

The law from other jurisdictions in Canada suggested that Alberta courts would generally interpret serious impairment as more than a mere inconvenience or loss of some enjoyment of life. The Alberta MIR requires a "substantial inability" for the claimant to pursue normal activities of his or her daily living, rather than mere "substantial interference" with the ability cited by the Ontario legislation, suggesting that the Alberta legislation requires an even more significant interference with a claimant's daily living before a finding of a serious impairment is made.

To date, however, the only guidance provided regarding the interpretation of serious impairment tends to interpret the term even more broadly than do the Ontario courts, despite the arguably higher threshold required by the Alberta legislation. This guidance comes from obiter dicta found in the decision of the Honourable Madam Justice Shelly in Sparrowhawk. Justice Shelley is the first Alberta jurist to opine at some length on what constitutes a "serious impairment" for the purposes of the MIR.

Mr. Sparrowhawk sustained jaw pain immediately after his rear-end accident, which was accompanied by popping and grinding sounds. This injury had not resolved by the time of trial. Sparrowhawk's expert testified that the grinding and popping, as well as the aberrant movement of his jaw, suggested joint derangement involving the cartilage. Moreover, there had been some unusual wear to the surface of Sparrowhawk's teeth, likely the result of grinding. After his injury, Sparrowhawk was able to continue working and was able to carry out all of his activities of daily living. However, as a result of this injury, Sparrowhawk had difficulty and pain associated when chewing, yawning, and speaking. ${ }^{47}$

Justice Shelley found that Sparrowhawk's injuries were not minor injuries. The rationale for her decision was that tooth and cartilage injuries do not involve muscle, tendon, ligament, or WAD injuries, and therefore do not fit into the definition of a minor injury. ${ }^{48}$ This finding alone is likely reasonable and was sufficient to dispose of the claim. However, Justice Shelley went on to comment that Mr. Sparrowhawk's jaw injury resulted in a serious impairment. 
Justice Shelley suggested that the evaluation of serious impairment under the MIR included five distinct requirements. It was necessary in each case to look at each of the following:

1. [W]hether a physical or cognitive function is impaired;

2. whether a sprain, strain, or WAD injury is "the primary factor contributing to the impairment";

3. does the impairment cause substantial inability to perform:
a. essential work tasks,
b. essential facets of training or education, or
c. "normal activities of the claimant's daily living”;

4. whether the impairment has been "ongoing since the accident”; and

5. whether the impairment is not expected to "improve substantially". 49

\section{CANAdian CASE LAW ON THE "SERIOUS IMPAIRMENT" FACTORS IDENTIFIED IN SPARROWHAWK}

Whether Justice Shelly's definition of substantial inability is ultimately followed by other Alberta courts or not, she has effectively summarized the five factors found in the MIR that must be considered by courts in analyzing whether a claimant has suffered a serious impairment. However, until Alberta builds up some case law surrounding these five factors, their best interpretation is arrived at by considering the decisions of other jurisdictions on the same or similar wording. The authors therefore review the relevant case law from other Canadian jurisdictions on these factors.

\section{1. “IMPAIRMENT OF PHYSICAL OR COGNITIVE FunCTION”}

In Rossignol v. Rubidge, ${ }^{50}$ the plaintiff had suffered a tibia/fibula fracture, but the injury had healed and he did not have any physical limitations arising from the injury. However, the plaintiff had deconditioned substantially and his former strong interest in athletics had declined. He was abusing alcohol and drugs, allegedly because he suffered post-traumatic stress disorder from the accident. The New Brunswick Court of Queen's Bench found that since the plaintiff did not in fact suffer from any limitations from the injury, there was no permanent serious impairment of any bodily function, let alone an important one, and therefore the injury was a minor personal injury. ${ }^{51}$ 
In Page v. Primeau, ${ }^{52}$ the plaintiff had suffered whiplash and cervical spine injuries that resulted in myofascial pain syndrome and a permanent limitation of range of motion (as myofascial pain has an uncertain outcome and indefinite duration). The Ontario Superior Court of Justice held that the plaintiff had indeed suffered an impairment of a physical, mental, or psychological function due to the said limitation of range of motion (however, in that case the Court held the impairment was not serious). ${ }^{53}$

In McAllan v. Carswell, ${ }^{54}$ the plaintiff sustained a large laceration to her head, which required six staples to close. The plaintiff alleged to suffer from constant headaches that affected her ability to be a worker, a mother, and a homemaker. More than one doctor confirmed that the headaches suffered by the plaintiff would be permanent. The Ontario Superior Court of Justice concluded that the impairments suffered by the plaintiff were permanent, serious, and of an important physical function. ${ }^{55}$

While the above cases may provide good indication of what constitutes an impairment of physical or cognitive function, Alberta lawyers should exercise caution due to the difference in statutory language across the provinces. While the New Brunswick Court in Rossignol denied a serious impairment claim based on lack of physical limitations post-accident, an Alberta court may find a claim arising out of identical facts to be valid. Alberta uses a broader definition of serious impairment, which captures not only physical, but also cognitive functions. Conversely, an Alberta court may not find a serious impairment on the facts that could give rise to such a finding in Ontario, as the latter province employs an even broader reference to any physical, mental, or psychological function.

On its face, in Sparrowhawk Justice Shelly did not devote much analysis to this branch, finding that the jaw dysfunction and associated pain was simply an impairment of a physical function. ${ }^{56}$ This is a reasonable conclusion. The potential issue arises because this is the same standard and factors applied to determine whether the impairment of a physical function was also a serious impairment, suggesting no difference at all between a physical impairment and a serious impairment, thereby rendering the third factor irrelevant.

\section{THE "PRIMARY CONTRIBUTING FACTOR”}

Although concluding that Sparrowhawk's jaw injury was not of the type that could attract minor injury consideration, Justice Shelly commented that a full analysis of serious impairment also considers whether the sprain, strain, or WAD is the primary contributing factor to the impairment. ${ }^{57}$ Justice Shelly further commented, without deciding, that "primary factor" could be assessed under the "largest contributing cause" test or under the tort law "but for" test, citing the Supreme Court of Canada's decision in Resurfice Corp. v. Hanke. ${ }^{58}$ An analysis of the application of these two different causation tests, as well as their applicability to the MIR, is outside the scope of this article, but it is clear that the issue of

[2005] OJ no 4693 (QL) (Sup Ct J) [Page].

Ibid at paras 29, 39.

2011 ONSC 86, [2011] OJ no 111 (QL).

Ibid at paras 29-34.

Supra note 4 at para 98.

Ibid at para 99.

[2007] 1 SCR 333 at paras 21-23, cited in Sparrowhawk, ibid at para 100. 
what constitutes the primary contributing factor will be the subject of discussion by Alberta courts in the future.

\section{3. “That Results in A Substantial InABility to PeRForm”}

In Fraser v. Haines, ${ }^{59}$ the New Brunswick Court of Appeal noted that the qualifier "serious" in "serious impairment" applied not to the injury itself but to "the impairment, which brings into play the effect of the injury." ${ }^{60}$ In other words, an injury may be serious, yet that does not mean there has been a serious impairment. Hence, the non-pecuniary damages cap may apply even to serious injuries. This position has been codified in Alberta in the section 1 requirement that a serious impairment must result in substantial inability to perform one of the listed tasks. ${ }^{61}$

Apart from this, non-Alberta case law provides limited value in assessing whether impairment resulted in substantial inability to carry out regular employment or normal activities of daily living. The definition of a serious impairment in all of the other three provinces requires merely substantial interference with the said activities, arguably a significantly lower threshold compared to Alberta. Therefore, what has been found to amount to substantial interference with regular employment or activities of daily living in Ontario may not be sufficient to amount to substantial inability to carry out the same tasks in Alberta.

Of the five evaluative factors, Justice Shelley devoted most of her analysis to the third step, opining that the most difficult hurdle for Sparrowhawk was establishing that the impairment caused a substantial inability to perform normal activities of daily living for the purposes of section $1 .^{62}$

\section{a. “Essential Tasks of the Claimant's Regular Employment”}

The following cases illustrate what courts across Canada have found to be a substantial interference with regular employment and normal activities of daily life. We encourage the reader to approach these cases with caution, bearing in mind the potentially higher threshold employed in Alberta's definition of a serious impairment.

In Lento v. Castaldo, ${ }^{63}$ heard together with Meyer, the plaintiff was a journeyman auto mechanic who had been employed for seven years prior to the accident and enjoyed good prospects. He sustained injuries to one hand and foot. The foot injury made it difficult to wear safety boots and the plaintiff was limited in his squatting and kneeling. The hand injury resulted in lost dexterity and sensation, as well as pain from use. The Ontario Court of Appeal concluded that the lost functions were important for the plaintiff as an auto mechanic. The Court commented generally that where the permanent impairment "frustrates the chosen 
career path of an injured person ... the impairment is properly described as being a serious one for that person." 64

In Page, discussed above, the plaintiff had suffered whiplash and cervical spine injuries that resulted in limitation of range of motion. Although the Court did find an impairment of a physical, mental, or psychological function, it did not find substantial interference with the plaintiff's ability to continue her regular employment. The plaintiff continued to work regular hours, and although she could no longer do heavy lifting, it was not an important part of her job. This was not sufficient to find substantial interference. ${ }^{65}$

In Firth v. Resendes, ${ }^{66}$ the plaintiff suffered soft tissue injuries in the accident, but video surveillance footage showed he could do strenuous physical work. The evidence also disclosed that he had returned to his pre-accident activity of completing the renovations to his house. As a result, the Ontario Superior Court of Justice found that the plaintiff had not sustained a serious impairment. ${ }^{67}$

In Goodridge (Litigation guardian of) $v . K i n g,{ }^{68}$ the plaintiff sustained a permanent impairment to the left wrist (her dominant hand). The injury affected her employment and her ability to perform activities of daily living. The final medical report stated that the discomfort was likely to have an impact on her future activities and on her work as a kindergarten teacher or even as a waitress or bartender. However, the Ontario Superior Court of Justice noted that the plaintiff had been able to maintain employment in the summer months to attend university, and to take guitar lessons. Consequently, the Court did not consider the injury to the wrist to be serious. ${ }^{69}$

In Nissan, also discussed above, the plaintiff had been working part-time with a housekeeping company for six to seven months before her accident occurred. Prior to that, she had been unemployed for a few months, and, before that, she had worked for several years in a pizza shop. Less than five months after the accident, the plaintiff returned to "work-like" duties (working weekend shifts from 5 p.m. to 3 a.m. three nights a week) at the pizza shop. Surveillance video showed the plaintiff preparing pizza dough, reaching up to the shelves, cleaning, moving her head and body freely, and "performing all duties that one would expect of a manager of a pizza shop."70 As well, the housekeeping company was willing to grant her accommodations (reduced hours and working with a partner), which she did not seek out or use. The Court found that the reported complaints did not substantially interfere with her ability to continue her regular employment, and thus she had not suffered a serious impairment. ${ }^{71}$ 
The Ontario Superior Court of Justice reached a different decision on similar facts in Hayden $v$. Stevenson. ${ }^{72}$ In that case, the plaintiff was training to be an automotive mechanic and his injuries resulted in continuous mid to low back pain, anxiety, depression, and sleep difficulties. The Court admitted and considered video surveillance footage showing the plaintiff sitting, crouching, bending, and lifting heavy objects. Nevertheless, the Court found, relying on Brak, that the plaintiff had suffered a serious impairment, as these activities caused him pain at the end of his day.

\section{b. "Essential Tasks of the Claimant's Training or Education”}

This factor has not generated as much jurisprudence, chiefly because it can only be found in the Ontario and Alberta definitions of a serious impairment. In Hayden, discussed above, the Court found that after the accident, the plaintiff was unable to return to a co-op program in the automotive field in which he was enrolled prior to the accident due to his back pain. This was sufficient to find a serious impairment. ${ }^{73}$

\section{c. “Normal Activities of the Claimant's Daily Living”}

In Dalgliesh v. Green, ${ }^{74}$ decided and reported together with Meyer, the Ontario Court of Appeal considered whether the plaintiff's loss of spleen and soft-tissue injuries interfered with her usual activities of daily living. After the accident, Mrs. Dalgliesh was still able to perform most of the tasks that she could previously, but she had to do them more slowly and give up the chores she used to perform outside the house. The Court found that this was not sufficient to qualify as a serious impairment and restated its earlier finding that "the legislature intended that injured persons are required to bear some detrimental impact upon their lives without being able to sue for it." 75

In Sherman v. Guckelsberger, ${ }^{76}$ even though the plaintiff cut her working hours after the accident, she continued to go on annual camping trips with her family and work out for at least one hour five days a week. Even though she constantly complained of headaches, neck pain, numbness, and tingling, the Ontario Superior Court of Justice found that the plaintiff had not suffered a substantial interference with her normal activities of daily living. ${ }^{77}$

In Firth, discussed above, the Ontario Superior Court of Justice looked to the plaintiff's hobbies and recreational activities to determine whether the impairment interfered with the activities of his daily living. They found that the plaintiff had returned to such physically demanding hobbies as square dancing, jogging, biking, rowing, and playing volleyball. As a result, the Court found that he had not suffered any permanent serious injury. ${ }^{78}$

(2009), 75 CCLI (4th) 149 (Ont Sup Ct J) [Hayden].

Ibid at paras 27-29.

(1993), 15 OR (3d) 129 (CA).

Ibid at 155.

[2008] OJ no 5322 (QL) (Sup Ct J).

Ibid at paras 145-47.

Supra note 66 at 12 . 
In McDonald v. Kwan, ${ }^{79}$ the plaintiff suffered chronic pain, stress, anxiety disorders, and associated problems. As a result of these maladies, the plaintiff took a long-term disability leave from which he never returned. The plaintiff could not engage in his usual physical and social activities. Most importantly, his ability to work was substantially diminished. The Ontario Superior Court of Justice found that the plaintiff was unable to carry on the normal activities of daily living. ${ }^{80}$

In Valdez v. Clarke, ${ }^{81}$ the plaintiff suffered a chronic pain syndrome, as well as numbness and tingling sensation in his right thumb and fingers. As a result of his injuries, the Ontario Superior Court found that the ongoing loss of Mr. Valdez's secondary employment, and his diminished level of social and recreational activity, achieved the threshold of serious impairment. Specifically, the Court noted the following:

1. While he was able to resume his primary job post-accident, Valdez was unable to return to his "secondary employment";

2. Valdez had given up two of his former passions: cooking and photography;

3. While Valdez had previously been socially active, following the accident he did virtually nothing anymore other than his job;

4. Valdez was no longer active in sports with his son and no longer played with his children;

5. Valdez no longer shopped for the family and required help dressing;

6. Valdez was irritable, impatient, and short-tempered in a way that he had not been prior to the accident; and

7. Valdez's emotional relationship with his son had suffered such that his son stopped visiting him every other weekend as he had done previously. ${ }^{82}$

In the end, Valdez was able to show substantial inability to perform the essential tasks of his regular occupation and his activities of daily living. The Court, again applying Brak, found that the plaintiff's pain "seriously affect[ed] his 'enjoyment of life, ability to socialize with others ... enjoy their children and engage in recreational pursuits.”,83

In this case, Justice Milanetti noted that the legislation in Ontario provides that for an injury to meet the threshold of a permanent and serious impairment of a physical, mental, or psychological function, it must either:

2010 ONSC 5861, [2010] OJ no 4511 (QL).

Ibid at paras 262-66.

2010 ONSC 174, 80 CCLI (4th) 248 [Valdez].

Ibid at paras 58-65.

Ibid at para 68, citing Brak, supra note 41 at para 7. 
i. $\quad$ substantially interfere with the person's ability to continue his or her regular or usual employment, despite reasonable efforts to accommodate the person's impairment and the person's reasonable efforts to use the accommodation to allow the person to continue employment...

ii. substantially interfere with the person's ability to continue training for a career in a field in which the person was being trained before the incident, despite reasonable efforts to accommodate the person's impairment and the person's reasonable efforts to use the accommodation to allow the person to continue his or her training, or ...

iii. substantially interfere with most of the usual activities of daily living, considering the person's age. ${ }^{84}$

In Del Rio v. Lawrence, ${ }^{85}$ the Ontario Superior Court of Justice made a crucial observation that the accepted approach to "normal activities of daily living" has been changed by the decisions in May v. Casola, ${ }^{86}$ and Brak. Pulling the rationes decidendi of these two cases together, the Court concluded that "the motion court is obliged to consider whether or not the continuing pain seriously affects a plaintiff's enjoyment of life, including his or her ability to socialize with others, have intimate relations, enjoy his or her children, or engage in recreational pursuits." 87 The Court further noted that "this analysis must be undertaken even if the motion judge concludes that the plaintiff can otherwise 'function' at work and can take care of him or herself." 88 Applying these observations to the facts, the Court found that the plaintiff's pain condition substantially interfered with her quality of life. In the plaintiff's case, she was able to return to work and attend to her personal needs and grooming, but she was unable to do anything at home but lie down as a result of her pain. The Court made this finding notwithstanding the fact that Ms. Del Rio's pre-accident routine was not nearly as active as that of some other plaintiffs.

The above pre-Sparrowhawk cases seem to indicate that courts will almost certainly look to the hobbies and recreational activities the claimant engaged in before the accident in order to assess whether the injury substantially interfered with normal activities of his or her daily living. Since each assessment is done on its own facts, a court may find such interference notwithstanding the fact that the plaintiff's pre-accident routine did not involve significant level of activity. Furthermore, successful return to regular employment may not be fatal to serious impairment claims. Although the Ontario courts previously ruled that the Legislature must have intended claimants to endure some pain without being able to sue, motion judges in Ontario are now obliged to consider whether the continuing pain seriously affects a plaintiff's enjoyment of life, notwithstanding that the plaintiff is able to return to work and attend to their personal needs. Since the Alberta "daily living” provision is worded similarly to the one found in Ontario, this analysis may apply in Alberta courts as well.

The real emphasis of Justice Shelly's obiter remarks in Sparrowhawk was on the third of these requirements, in considering what constituted a substantial inability to carry out one's normal activities of daily living (the plaintiff had not had any interference with his work and

Valdez, ibid at para 54 [emphasis in original].

[2009] OJ no $676(\mathrm{QL})$ at para 7 (Sup Ct J) [Del Rio].

[1998] OJ no 2475 (QL) (CA) [May].

Del Rio, supra note 85 at para 7.

Ibid. 
was not undergoing any training or education). Justice Shelly found that mere difficulty with a task should be sufficient to constitute a substantial inability to do it. ${ }^{89}$ Justice Shelley found support for this view in Ontario's interpretation of substantial interference, suggesting that the two standards were analogous, without doing any significant analysis of whether a condition that interferes with a task (Ontario) is really equivalent to a condition resulting in an inability to do a task (Alberta). ${ }^{90}$

Ultimately, Justice Shelly determined that a serious impairment as defined by the MIR will exist whenever an injury:

1. [P]revents an injured person from engaging in a "normal activity of daily living",

2. impedes an injured person's engaging in a “normal activity of daily living” to a degree that is non-trivial for that person, [or]

3. does not impede an injured person from engaging in a "normal activity of daily living” but that activity is associated with pain or other discomforting effects such that engaging in the activity diminishes the injured person's enjoyment of life. ${ }^{91}$

While the first two of these might well fit within the definition of substantial inability, it is difficult to see how the third can be considered any sort of inability, when by definition the claimant suffered no impediment from engaging in his or her normal daily living activities. While the third category may well fit within Ontario's broader definition of substantial interference, its inclusion of this third category in Alberta's more restrictive definition could well be a point of contention in future "serious impairment” cases in Alberta.

\section{4. “ONGOING SinCE THE ACCIDENT, AND ... NOT EXPECTED TO IMPROVE SUBSTANTIALLY”}

The last two factors to be considered in the analysis of whether an injury constitutes a serious impairment is permanence. The idea of permanence is found in the minor injury legislation of all four jurisdictions. The definition employed in Alberta largely represents codification of various Ontario decisions on the issue.

For instance, in dealing with the permanent component, the Ontario Court of Appeal in May indicated:

In our view a person who can carry on daily activities, but is subject to permanent symptoms including, sleep disorder, severe neck pain, headaches, dizziness and nausea which, as found by the trial judge, had a significant effect on her enjoyment of life must be considered as constituting serious impairment. ${ }^{92}$ 
Furthermore, the Ontario Court of Appeal in Brak established that a permanent injury meets the threshold if the limitation "is unlikely to improve for the indefinite future." ${ }^{93}$ Similarly, in Page, discussed above, the Ontario Superior Court of Justice found the plaintiff's impairment to be permanent, as myofascial pain syndrome had indefinite duration with an uncertain outcome. $^{94}$

In sum, non-Alberta case law seems to confirm that the permanence of the impairment will be assessed according to the two legislative criteria. It will most likely also be subject to the now codified Ontario requirement that the person must reasonably participate in the recommended treatment, as this requirement simply represents the common law duty to mitigate one's loss.

In Sparrowhawk, Justice Shelly concluded that the "ongoing” criterion in the definition of serious impairment means that the impairment persists over time even though the degree of dysfunction may be variable. ${ }^{95}$ Her ladyship found that the plaintiff experienced a daily progression in dysfunction for over six years, constituting ongoing impairment and meeting this criterion in the serious impairment analysis. ${ }^{96}$

Justice Shelly went on to find that substantial improvement did not mean "any improvement," but rather that the injury or dysfunction could not be expected to improve to such a degree that the substantial inability would cease. ${ }^{97}$ Justice Shelly noted that substantial improvement was evaluated on a subjective basis specific to the individual, unlike the Ontario regulations, which required evaluating "substantial improvement when sustained by persons in similar circumstances."

Her ladyship went on to find that utilizing an interpretation of improve substantially was necessary to give effect to the remedial character of the MIR and the minor injury scheme. ${ }^{99}$ Justice Shelly then concluded that "the use of the same word, 'substantial', to describe both the inability and improvement was intentional and intended to create symmetry: an injury is not a minor injury if it causes 'substantial' inability; 'substantial' improvement is sufficient improvement to negate the 'substantial' inability."100

\section{CONCLUSION}

The definition of a "serious impairment" contained in section 1 of the Alberta MIR appears to be a codification of the Ontario jurisprudence dealing with the definition of the term. Nevertheless, the wording used in Alberta is different in a number of aspects from that used in Ontario and other provinces. The three major differences of the Alberta legislation are: (1) complete absence of the requirement that the impaired bodily function be "important"; (2) a more onerous requirement that the impairment result in a "substantial 
inability" to perform enumerated functions, as opposed to mere "substantial interference" with the claimant's ability to perform the said functions; and (3) the less onerous requirement to establish either substantial inability to perform the essential tasks of the claimant's regular occupation or activities of daily living.

As a result of these differences, non-Alberta jurisprudence, even post-Sparrowhawk, must be approached with caution, bearing in mind particularly the higher threshold that needs to be crossed in Alberta. Nevertheless, the said jurisprudence may be of some value to Alberta litigators. In particular, it shows that a serious impairment does not mean "significant" or "approaching catastrophic" and that each case will be decided on its own facts. Although Sparrowhawk went a long way in providing a taste of how the Alberta judiciary may apply the serious impairment criterion in the MIR to factual scenarios, it is noted that Justice Shelley's comments on this issue are obiter.

It seems reasonable (given the distinction in the MIR between a physical impairment and a serious impairment) that Alberta courts will expect an injury to result in some degree of pain or discomfort before determining that it should fall outside the minor injury cap. In assessing whether the injury results in a serious impairment in the circumstances of a particular plaintiff, the court will look to that person's pre-accident activities and use all available evidence to ascertain the extent to which the plaintiff was able to return to these activities. Finally, after the decision in Brak, the Ontario courts now must consider whether continuing pain seriously affects the claimant's enjoyment of life, notwithstanding that he or she was able to return to his pre-accident activities. Whether this approach and other approaches discussed in this article will apply in the Alberta courts, given the differences in the wording of the relevant legislation, remains to be seen.

\section{APPENDIX: \\ SERIOUS IMPAIRMENT ACROSS JURISDICTIONS}

\begin{tabular}{|c|c|c|c|}
\hline Alberta & Ontario (current) & New Brunswick & Nova Scotia \\
\hline $\begin{array}{l}\text { Minor injury is one that does } \\
\text { not result in "serious } \\
\text { impairment" }\end{array}$ & $\begin{array}{l}\text { No liability unless there is } \\
\text { "permanent serious } \\
\text { impairment”... }\end{array}$ & $\begin{array}{l}\text { Minor injury is one that does } \\
\text { not result in "permanent } \\
\text { serious impairment"... }\end{array}$ & $\begin{array}{l}\text { Minor injury is one that does } \\
\text { not result in "permanent } \\
\text { serious impairment"... }\end{array}$ \\
\hline $\begin{array}{l}\text { "of a physical or cognitive } \\
\text { function" }\end{array}$ & $\begin{array}{l}\text { "of an important physical, } \\
\text { mental or psychological } \\
\text { function" }\end{array}$ & $\begin{array}{l}\text { "of an important bodily } \\
\text { function" }\end{array}$ & $\begin{array}{l}\text { "of an important bodily } \\
\text { function" }\end{array}$ \\
\hline $\begin{array}{l}\text { "that results in a substantial } \\
\text { inability to perform" }\end{array}$ & $\begin{array}{l}\text { But only if the impairment } \\
\text { "substantially interferes with } \\
\text { the person's ability to" }\end{array}$ & $\begin{array}{l}\text { Serious impairment if it } \\
\text { "causes substantial } \\
\text { interference with a person's } \\
\text { ability to" }\end{array}$ & $\begin{array}{l}\text { Serious impairment if it } \\
\text { "causes substantial } \\
\text { interference with a person's } \\
\text { ability to" }\end{array}$ \\
\hline
\end{tabular}




\begin{tabular}{|c|c|c|c|}
\hline Alberta & Ontario (current) & New Brunswick & Nova Scotia \\
\hline $\begin{array}{l}\text { "the essential tasks of the } \\
\text { claimant's regular } \\
\text { employment, occupation or } \\
\text { profession" }\end{array}$ & $\begin{array}{l}\text { "continue his or her regular or } \\
\text { usual employment” and a } \\
\text { function is important if it was } \\
\text { "necessary to perform the } \\
\text { activities that are essential } \\
\text { tasks of the person's regular } \\
\text { or usual employment” }\end{array}$ & $\begin{array}{l}\text { "perform their ...regular } \\
\text { employment" }\end{array}$ & $\begin{array}{l}\text { "perform their ...regular } \\
\text { employment," and regular } \\
\text { employment means "the } \\
\text { essential elements of the } \\
\text { activities required by the } \\
\text { person's pre-accident } \\
\text { employment" }\end{array}$ \\
\hline $\begin{array}{l}\text { “despite reasonable efforts to } \\
\text { accommodate the claimant's } \\
\text { impairment and the claimant's } \\
\text { reasonable efforts to use the } \\
\text { accommodation to allow the } \\
\text { claimant to continue the } \\
\text { claimant's employment, } \\
\text { occupation or profession” }\end{array}$ & $\begin{array}{l}\text { “despite reasonable efforts to } \\
\text { accommodate the person's } \\
\text { impairment and the person's } \\
\text { reasonable efforts to use the } \\
\text { accommodation to allow the } \\
\text { person to continue } \\
\text { employment” }\end{array}$ & N/A & $\begin{array}{l}\text { Substantial interference means } \\
\text { that the person is unable to } \\
\text { perform "after reasonable } \\
\text { accommodation by the person } \\
\text { or the person's employer for } \\
\text { the personal injury and } \\
\text { reasonable efforts by the } \\
\text { injured person to adjust to the } \\
\text { accommodation" }\end{array}$ \\
\hline $\begin{array}{l}\text { Or, "substantial inability to } \\
\text { perform ... normal activities } \\
\text { of the claimant's daily living" }\end{array}$ & $\begin{array}{l}\text { "substantially interferes with } \\
\text { most of the usual activities of } \\
\text { daily living, considering the } \\
\text { person's age" }\end{array}$ & $\begin{array}{l}\text { "perform their usual daily } \\
\text { activities" }\end{array}$ & $\begin{array}{l}\text { "perform their usual daily } \\
\text { activities" }\end{array}$ \\
\hline $\begin{array}{l}\text { A serious impairment must } \\
\text { also be "ongoing since the } \\
\text { accident ... and ... that is } \\
\text { expected not to improve } \\
\text { substantially." }\end{array}$ & $\begin{array}{l}\text { A permanent serious } \\
\text { impairment is permanent if it } \\
\text { is "continuous since the } \\
\text { incident" and "based on } \\
\text { medical evidence and subject } \\
\text { to the person reasonably } \\
\text { participating in the } \\
\text { recommended treatment of the } \\
\text { impairment, be expected not } \\
\text { to substantially improve." }\end{array}$ & $\begin{array}{l}\text { Permanent serious impairment } \\
\text { is "caused by continuing } \\
\text { injury which is physical in } \\
\text { nature." }\end{array}$ & $\begin{array}{l}\text { Minor injury is injury that } \\
\text { does not result in permanent } \\
\text { serious impairment that } \\
\text { "resolves within } 12 \text { months } \\
\text { following the accident." }\end{array}$ \\
\hline
\end{tabular}

